\title{
Do law enforcement expenditures crowd-out public education expenditures?
}

\author{
MICHAEL L. MARLOW and ALDEN F. SHIERS \\ Department of Economics, California Polytechnic State University, San Luis Obispo, \\ CA 93407, USA
}

As state and local governments have devoted a rising share of their resources to crime-related programmes, concerns have arisen that spending on other programmes such as education will fall. Coupled with growing public concerns over performance of the public education system, and expectations that prison populations will rise as states pass and enforce more stringent sentencing laws, it is not surprising that some view the expansion of crime-related programmes as troublesome. One hypothesis is that education and crime-related programmes directly compete for government expenditures so that what one programme gains the other must lose as in a fixed-pie situation. A competing hypothesis is that spending on these two public programmes are unrelated and therefore higher crime-related spending may also lead to higher taxes or public debt issuance, or to reduction in spending on programmes other than education. We estimate a three equation model of spending on crime-related programmes, spending on education, and the crime rate from which we directly test whether spending on crime and education influence each other.

\section{INTRODUCTION}

Government spending on crime-related programmes and law enforcement has received growing and considerable public attention in recent years. According to recent Department of Justice reports, ${ }^{1}$ three cents of every government dollar in fiscal year 1990 went for justice activities, including police protection, jails and prisons, and the courts. Most dollars are spent by state and local governments as they accounted for $87 \%$ of total (federal, state and local) expenditures of US \$74 billion for civil and criminal justice in fiscal year 1990, a 22\% increase over 1988. On a per capita basis, the three levels of government together spent US \$299. By year-end 1995, 5.3 million people were on probation, in jail or prison, or on parole - nearly $2.8 \%$ of all US adult residents - and state and federal prisons held 1.1 million prisoners. Local jails held another 507044 adults who were awaiting trial or serving a sentence at mid-year 1995.

Public spending on education is another area that attracts considerable public attention. When compared to other industrialized economies, US schools appear to perform poorly, and a common perception is that conditions are worsening over time. ${ }^{2}$ It is often argued that spending has declined, but public education spending (1989-90 dollars) per pupil rose $74 \%$ from 1960 to 1992 , or from roughly US \$2979 to $\$ 5196 .^{3}$ At the same time, and despite this spending increase, combined SAT (Student Achievement Test) scores fell $5.2 \%$, or from 948 to 899 over this same period. ${ }^{4}$ Despite the spending expansion, growing support for further expansion of education spending is advocated by those who believe that spending expansion is necessary if the purported decline in student performance is to be reversed. ${ }^{5}$

\footnotetext{
${ }^{1}$ Statistics reported here are from Bureau of Justice Statistics, Expenditure and Employment Statistics, 1997.

${ }^{2}$ See Peltzman (1993)

${ }^{3}$ Statistical Abstract of the United States (1993) Tables 221 and 222.

${ }^{4}$ Statistical Abstract of the United States (1993) Tables 265.

${ }^{5}$ There is also growing support for other means of providing services such as charter schools and vouchers systems that allow greater school choice for parents.
} 
Given the desire to expand education spending, it is not surprising that its proponents view the expansion of crimerelated government spending as troublesome, either because they believe that it siphons off dollars that could be used for education, or because of the view that fewer dollars spent on education today lead to greater expenditures on crimerelated programmes tomorrow as less-educated students are more likely to become criminals in the future. For example, passage in California of 'three strikes and you are out' legislation has led some educators and parents to fear that, as it leads to higher crime-related expenditures - especially those related to incarceration of criminals - a continual and rapid diminution of expenditures on education will follow. A recent study by the Rand Corporation (Greenwood et al., 1994) predicts that California's 'three strikes' law carries a price tag of US $\$ 5.5$ billion more in public spending on crime-related programmes. With more states taking a less lax attitude towards parole, and with more states considering legislation similar to California's 'three strikes' law, it appears that many states will witness growing commitments towards funding of crime-related programmes.

This paper examines the relationship between public spending on education and public spending on crimerelated programmes. As just discussed, it is often alleged, at least at the state and local government level, that education and crime-related programmes directly compete for government expenditures so that what one programme gains the other must lose as in a fixed-pie situation. Higher expenditures on crime-related programmes are therefore asserted to reduce, or crowd-out, expenditures on education. Of course, this is one hypothesis and a competing hypothesis is that spending on these two public programmes is unrelated and therefore higher crime-related spending may also lead to higher taxes to public debt issuance, or to reduction in spending on non-crime-related programmes. This paper examines whether state and local expenditures on crimerelated programmes crowd-out state and local expenditures on education. We estimate a three equation model of spending on crime-related programmes, spending on education, and the crime rate from which we directly test whether spending on crime and education influence each other.

\section{PREVIOUS STUDIES}

There has been little research conducted in the area of crowding-out among programmes of state and local governments. A review of this literature indicates that little or no evidence has been found to suggest any support for the hypothesis that higher crime-related funding, or funding of any programme for that matter, crowds-out funding on education.

Brazer and McCarty (1987) test the 'municipal overburden' hypothesis that high demand for municipal services lowers the demand for public elementary and secondary education. This hypothesis suggests that those areas, primarily urban, that require relatively higher expenditures directed towards dealing with poverty, aged housing, and crime will have fewer resources available for education funding. The authors concluded that empirical evidence offers no support for the 'municipal overburden' hypothesis in the cases of per pupil funding among school districts in Connecticut, New Jersey, and Virginia during 1981-82. However, they do find several cases where a positive correlation exists between municipal and education spending, which is in the opposite direction to that predicted by the 'municipal overburden' hypothesis.

Fossett and Wyckoff (1996) examine the impact of rising Medicaid spending on public elementary and secondary education spending. Using a two-stage, least squares fixed effects model, they test the hypothesis on data from 47 states from 1980 to 1990 . While an inverse relationship is estimated, it is not statistically significant and therefore the authors conclude that there is no support for the hypothesis.

McCarty and Schmidt (1997) examine interactions among six spending programmes of state governments for evidence of crowding-out over eleven years, 1984-94. The six programmes are elementary and secondary education, higher education, welfare, health and hospitals, corrections, and miscellaneous. They use a vector autoregression (VAR) model to examine whether changes in one programme are correlated with changes in other programmes, either over time or contemporaneously. No evidence of crowding-out is found. In most cases, when the programme's funding rises above-trend, it has no significant influence on future spending on other programmes. However, they found evidence that deviations from trend have significant influences on future own-programme spending which they interpret to indicate that higher above-trend spending in one programme is funded through higher tax revenues than through spending reduction in other programmes.

There is a literature that examines how incarceration affects the crime rate and ultimately expenditures on prisons. Clark and Lee (1996) hypothesize that increases in lengths of prison terms cause the demand for prison space to grow at a diminishing rate as criminals react to longer expected sentence lengths by committing fewer crimes. In other words, the deterrence effects of longer sentences are assumed to more than outweigh longer prison terms thus leading to an overall reduction in demand for prison space. An implication of the Clark and Lee (1996) hypothesis is that voters and policymakers who push for shorter prison sentences and resist expanding current prison space as means of lowering costs are actually causing greater incentives for criminal activity that ultimately lead to higher future costs as these policies lead to greater numbers of prisoners in the future. Cloninger (1996) argues that the Clark and Lee (1996) hypothesis rests on several assumptions that may be questionable, at least in the short-run, and suggests that effects of prison sentencing policies on 
demands for prison space are somewhat ambiguous. Clearly, this issue is extremely important when we consider that spending on prisons today have budgetary implications about spending on prisons tomorrow when such spending exerts significant deterrence effects on criminal activity. We address this issue in our model by examining whether past changes in crime-related spending exert effects on crime rates over time. ${ }^{6}$

Another related issue is developed in Brumm and Cloninger (1995) which examines whether there is a direct correlation between the 'war on drugs' and the homicide rate based on the hypothesis that the war on illicit drugs has diverted resources away from other law enforcement activities. If this is correct, Brumm and Cloninger (1995) predict that crime rates on non-drug-related activities are higher than they would otherwise be as the deterrence effect from law enforcement suffers under reduced funding. Empirical evidence is reported that is consistent with the hypothesis that homicide rates are higher in communities that allocate relatively high percentages of law enforcement expenditures in the area of drug enforcement. This issue is important for our paper because it suggests that crowding-out of government programmes may arise both between different programme categories (e.g., crime-related vs education vs military) and within specific programmes (e.g., corrections vs law enforcement vs anti-crime advertising). In the area of crime, there are many different subprogrammes and it is possible that one subprogramme such as corrections might crowd-out another subprogramme such as law enforcement. As just discussed, such an allocation may have implications for future spending when, for instance, fewer dollars allocated to law enforcement today leads to greater incentives for criminal activity that ultimately lead to more prisoners, and therefore prison space, in the future. We address this issue by separately examining total crime-related spending and corrections spending and therefore test whether these two types of crime-related spending exert differential effects on both crime rates and on education spending.

\section{EDUCATION AND CRIME-RELATED SPENDING EQUATIONS}

Education and crime-related expenditures are determined through the political process between voters and policy makers, within the budget (spending, tax, and debt) institutions of state and local governments. Within the budget processes of governments, education and crime-related expenditures are determined, along with expenditures in other budget categories. The total budget is then the sum of its component parts, where various demographic (e.g., age distribution), economic (e.g. unemployment rates), and cultural (e.g., past crime rates) characteristics then influence demand for individual spending programmes.

The following models of cross-state education and crimerelated spending are estimated:

$$
\begin{aligned}
& E D E X P_{i}=f\left(C R I M E_{i}, Y_{i}, E D U C_{i}, D E N S I T Y_{i},\right. \\
& \text { ST UDENT }{ }_{i}, S T A T E_{i}, F E D_{i}, S C H O O L S_{i}, \\
& \text { DIVERSIT } Y_{i} \text { ) } \\
& C R I M E_{i}=f\left(E D E X P_{i}, C R_{i}, C C R_{i}, D O M_{i}\right) \\
& C R_{i}=f\left(C R I M E_{i}, \text { DIVERSIT } Y_{i}, C R_{i-1}, Y_{i},\right. \\
& \left.M E D A G E_{i}, M I D 1_{i}, M I D 2_{i}, U E_{i}, C U E_{i}\right)
\end{aligned}
$$

See Table 1 for a description of the variables, and Table 2 for summary statistics of key variables. Per capita crime-related spending in 1992 averaged US\$273.63, with a low of US\$117.52 (West Virginia), and a high of US\$571.60 (Alaska). Per capita crime-related spending in 1985 averaged US\$155.41, with a low of US\$82.16 (West Virginia), and a high of US\$592.04 (Alaska). Education spending per pupil in 1992 averaged US\$5497.40, with a low of US\$3180.20 (Utah), and a high of US\$9415.20 (New Jersey). Education spending per pupil in 1985 averaged US\$4369, with a low of US\$2756 (Mississippi), and a high of US\$9689 (Alaska). The crime rate, as measured by crime offences (violent plus property) known to police per 100000 population in 1992 averaged 5085 with a low of 2610 (West Virginia) and a high of 8358 (Florida). In 1985, the crime rate averaged 4753, with a low of 2253 (West Virginia) and a high of 7574 (Florida).

\section{Dependent variables}

The dependent variables are educational expenditures $E D E X P_{i}$, crime expenditures $C R I M E_{i}$, and the crime rate $C R_{i}{ }^{7}$ The model is estimated twice, one for each of two years 1992 and 1985. These two years are chosen because they represent the longest time period for which consistent data on crime-related programmes is available.

\section{Educational spending equation}

Crime-related spending is included in the education spending equation to test the hypothesis that the two are intertwined in the public budget. A negative relation would

\footnotetext{
${ }^{6}$ See Buck (1996) and Smith (1996) for further appraisals of the Clark and Lee (1996) hypothesis.

${ }^{7}$ Notice that the connection between education spending and programme quality is ambiguous, as higher education spending could simply reflect higher compensation for school personnel or it could also reflect higher quality programmes. However, for our purposes, we are only interested in education spending because this appears to be the focus of the crime-education debate. See Marlow (1997) for a discussion of how numbers of schools influence education spending and student achievement.
} 


\begin{tabular}{ll}
$E D E X P_{i}$ & Current expenditures for public elementary and secondary education, per pupil. \\
$C R I M E_{i}$ & $\begin{array}{l}\text { Total crime-related expenditures of state and local governments, per pupil. Includes expenditures for police } \\
\text { protection, judicial, legal services and prosecution, public defence expenditure, corrections expenditure, and }\end{array}$ \\
& other justice expenditure. \\
$Y_{i}$ & Median family income of the population \\
$E D U C_{i}$ & Percentage of population with high school degrees \\
$D E N S I T Y_{i}$ & Percentage of population living in metropolitan areas \\
$S T U D E N T_{i}$ & Elementary and secondary student percentage of population \\
$S T A T E_{i}$ & Percentage of education funding from state government \\
$F E D_{i}$ & Percentage of education funding from federal government \\
$S C H O O L S_{i}$ & Number of schools per 1000 students \\
$D I V_{i}$ & Index of racial/ethnic diversity; the higher the value, the less diverse the population \\
$C R_{i}$ & Crime offences known to police per 100000 population; includes both violent and property crime \\
$C C R_{i}$ & Change in crime rate (three-year change) \\
$M E D A G E_{i}$ & Median age of population \\
$M I D 1_{i}$ & Percentage of population aged 18-24 \\
$M I D 2_{i}$ & Percentage of population aged 25-44 \\
$D O M_{i}$ & Percentage of justice-related employees in population, includes police protection, judicial, legal services and \\
$U E_{i}$ & prosecution, public defence, corrections, and other justice employees. \\
$C U E_{i}$ & Civilian unemployment rate \\
\hline
\end{tabular}

suggest that higher crime-related spending crowds-out education spending. A positive relation would suggest that higher spending on crime-related programmes leads to higher spending on education, or that states that allocate relatively many resources to crime-related programmes also allocate relatively many resources to education programmes. No relationship would suggest no linkage between the two spending programmes in the public budget.

The median voter theorem predicts that median voters dominate spending decisions. Median family income $Y_{i}$ is therefore hypothesized to be positively related to education spending. Higher educated voter are hypothesized to vote for more education and therefore a positive coefficient is hypothesized for $E D U C_{i}$, percentage of population with high school degrees. Population density DENSIT $Y_{i}$ measures the percentage of the population living in metropolitan areas and, because production costs are commonly believed to be higher in metropolitan areas, it is hypothesized to be positively related to education spending. The student percentage of the population $S T U D E N T_{i}$ controls for cross-state differences in student populations and is hypothesized to exert positive influences on education spending because higher values may reflect greater parental demands for education.

The state share of education funding $S T A T E_{i}$, controls for the Brennan and Buchanan (1980) hypothesis that more centralized funding leads to the perception by taxpayers that local funding burdens are lower than under less centralized funding. ${ }^{8}$ That is, the lower the cost of education perceived by taxpayers, the greater the demand for public education. A positive effect from the state share of funding is therefore hypothesized. ${ }^{9}$ The federal share of education funding $F E D_{i}$ is hypothesized to exert similar influences on public education spending; i.e., a higher value of $F E D_{i}$ leads to higher education spending if the cost perceived by state and local taxpayers falls.

The relationship between numbers of schools and educational expenditures is theoretically indeterminate. Substantial economies of scale could be unexploited when there are relatively many schools so that a greater number of schools is associated with higher expenditures. But, a large number of schools could also be an indication of vigorous competition among governments, or school districts, with educational services delivered at low cost. ${ }^{10}$ The Leviathan model

\footnotetext{
${ }^{8}$ Winer (1983) and Logan (1986) argue that higher values of grants lower financing burdens, as perceived by taxpayers, and leads to higher overall government spending.

${ }^{9}$ Moreover, if higher values of $S T A T E_{i}$ lead to greater spending equalization among schools and school districts, then there may also be fewer quality differences within a state's public education system and therefore fewer potential gains that parents may experience by relocating to another school district or school within a state. Because greater equalization lowers the gains to exiting, or in the Brennan and Buchanan (1980) view lowers the level of intergovernmental competition, this is hypothesized to lead to higher spending as well.

${ }^{10}$ There is some evidence that past school district consolidation has not exploited scale economies. Kenny and Schmidt (1994) find that numbers of school districts in states are always substantially greater than numbers that would be predicted based solely on attempts to gain greater scale economies.
} 


\begin{tabular}{|c|c|c|c|c|}
\hline Variable & Mean & Median & Minimum & Maximum \\
\hline \multicolumn{5}{|l|}{1992} \\
\hline Crime-related spending (per capita) & 273.63 & 259.30 & 117.52 & 571.60 \\
\hline Corrections spending (per capita) & 96.52 & 90.45 & 32.28 & 224.83 \\
\hline Primary and secondary education spending (per pupil) & 5497.4 & 5340.3 & 3180.2 & 9415.2 \\
\hline Crime rate & 5085 & 5081 & 2610 & 8358 \\
\hline Median household income & 30720 & 30278 & 42171 & 20301 \\
\hline $\begin{array}{l}\text { Per cent of population with High School Degree or } \\
\text { Higher, } 1990\end{array}$ & 76.3 & 76.8 & 64.3 & 86.6 \\
\hline Per cent of population in metropolitan areas & 66.7 & 69.6 & 24 & 100 \\
\hline Student share of population & 17.45 & 17.44 & 14.3 & 25.6 \\
\hline Number of schools per 1000 students & 2.47 & 2.11 & 1.27 & 5.61 \\
\hline State share of education funding & 49.0 & 47.6 & 8.5 & 90.6 \\
\hline Federal share of education funding & 7.0 & 6.2 & 3.6 & 16.4 \\
\hline Diversity index & 6930 & 7026 & 3864 & 9624 \\
\hline Median age of population & 33.5 & 33.6 & 26.6 & 36.6 \\
\hline Population share aged $18-24$ & 10.13 & 10.05 & 8.82 & 11.74 \\
\hline Population share aged $25-44$ & 31.88 & 31.78 & 28.80 & 37.64 \\
\hline Crime employees as share of population & 0.56 & 0.55 & 0.34 & 0.85 \\
\hline Correctional employees as share of population & 0.19 & 0.18 & 0.08 & 0.33 \\
\hline \multicolumn{5}{|l|}{1985} \\
\hline Crime-related spending (per capita) & 155.41 & 136.86 & 82.16 & 592.04 \\
\hline Corrections spending (per capita) & 47.86 & 41.68 & 17.38 & 234.11 \\
\hline Primary and secondary education spending (per pupil) & 4369 & 41.26 & 2756 & 9689 \\
\hline Crime rate & 4753 & 4627 & 2253 & 7574 \\
\hline Median household income & 32877 & 32339 & 22638 & 49264 \\
\hline $\begin{array}{l}\text { Per cent of population with High School Degree or } \\
\text { Higher, } 1980\end{array}$ & 67.5 & 68.0 & 53.1 & 82.5 \\
\hline Per cent of population in metropolitan areas & 63.4 & 66.4 & 19.1 & 100 \\
\hline Student share of population & 19.25 & 19.99 & 15.85 & 25.47 \\
\hline Numbers of schools per 1000 students & 2.32 & 1.85 & 1.17 & 5.61 \\
\hline State share of education funding & 49.78 & 47.71 & 8.11 & 90.86 \\
\hline Federal share of education funding & 6.86 & 6.43 & 2.93 & 17.83 \\
\hline Diversity index & 7247 & 7314 & 4134 & 9681 \\
\hline Median age of population & 31.1 & 31.2 & 25.4 & 35.5 \\
\hline Population share aged 18-24 & 12.1 & 12.1 & 10.4 & 13.3 \\
\hline Population share aged $25-44$ & 30.7 & 30.5 & 27.1 & 38.9 \\
\hline Crime employees as share of population & 0.50 & 0.46 & 0.34 & 0.80 \\
\hline Correctional employees as share population & 0.14 & 0.13 & 0.07 & 0.25 \\
\hline
\end{tabular}

of Brennan and Buchanan (1980) would predict that fewer schools lead to higher education spending because this reflects less intergovernmental competition in the public education market. The hypothesized sign on $S C H O O L S_{i}$, numbers of schools per 1000 students, is therefore an empirical question. ${ }^{1}$

The ethnic diversity of a state's population $D I V_{i}$ is expected to be positively related to educational expenditures. An ethnically diverse population often requires special education programmes that increase expenditures per pupil. An index of diversity was created for each state using race/ethnic groups reported by the Census Bureau: WhiteHispanic, Black-Hispanic, American Indian, Eskimo, Aleut-Hispanic, Asian Pacific Islander-Hispanic, White non-Hispanic, Black non-Hispanic, Aleut non-Hispanic and Asian Pacific Islander non-Hispanic. The diversity index was calculated as the sum of the squared percentage of the population of each group. The greater is the diversity index,

\footnotetext{
${ }^{11}$ An alternative measure, numbers of school districts per 1000 students, was also used, but because it yielded results very similar to numbers of schools per 1000 students, estimations using this measure are not shown here.
} 
the less racially/ethnically diverse is a state's population. A negative effect, or a more diverse population leads to greater expenditures, is therefore hypothesized.

\section{Crime spending equation}

Equation spending is included in the crime spending equation to test the hypothesis that the two are interrelated in the public budget. A negative relation would suggest that higher education spending crowds-out crime spending. A positive relation would suggest that higher spending on education leads to higher spending on crime, or that 'big' spenders on crime are also 'big' spenders on education. No relationship would suggest no linkage between the two programmes.

The crime rate $C R_{i}$, and its change over the previous three years $C C R_{i}$, are hypothesized to exert positive influences on crime spending. Higher crime rates, and higher recent increases in crime rates, are expected to raise crime-related spending as more resources are devoted to enforcement, court costs, incarceration, and prevention areas of public spending. As crime rates rise, the public may also demand higher expenditures, and given criminal codes and sentencing policies, greater crime activity results in higher public crime-related expenditures.

The dominance of crime-related employees in the population $D O M_{i}$ controls for two possible effects on spending. First, the simple fact that there are relatively more employees should lead to higher payrolls, and therefore spending as well. Second, crime-related employees are a special interest group with an interest in promoting spending on crime programmes, and therefore they will exert a stronger force on the political process that determines public budgeting. Because, in both cases, a positive influence from $D O M_{i}$ is hypothesized, higher shares of crime-related employees is hypothesized to lead to higher spending on crime programmes. While the average per cent of crime-related employees in the population is 0.56 , it has a fairly large range running from a high of 0.85 (New York) to a low of 0.34 (West Virginia) in 1992. ${ }^{12}$

\section{Crime rate equation}

Following the logic that crime-related spending deters criminal activity, the contemporaneous level of crimerelated spending is hypothesized to exert a negative influence on the crime rate. The ethnic diversity of a state's population $D I V_{i}$ is hypothesized to influence crime rates, based on the expectation that an ethnically diverse population creates greater cultural conflicts and tensions that result in higher crime rates. The previous year's crime rate, $C R_{i-1}$, is expected to exert a positive influence on the crime rate. Median income is hypothesized to exert a negative influence on the crime rate based on the economic argument that individuals find criminal activity more attractive as their (legal) opportunities to earn income fall.

We hypothesize that the more youthful the population, the higher are crime rates because a disproportion ate share of crimes is committed by juveniles and young adults. The following population variables are included: $M I D 1_{i}$ is percentage of population aged $18-24$, and $M I D 2_{i}$ is percentage of population aged 25-44. Higher values of both variables are expected to raise crime rates because a majority of crimes are committed within these age brackets. Median age, $M E D A G E_{i}$, is used to control for differences in median ages across the states.

The civilian unemployment rate $U E_{i}$ is hypothesized to be positively related to crime rates because, in those states with relatively fewer jobs, there may be a greater incentive for criminal activity. The three-year change in the unemployment rate $C U E_{i}$ is hypothesized to exert a positive influence on crime rates because, the higher a recent increase in unemployment, the greater the incentive for criminal activity. Use of $C U E_{i}$ also controls for the fact that some states have persistently high or low unemployment rates, as influenced by geographic or industrial characteristics, and therefore the very fact that a state has a relatively high unemployment rate does not necessarily always suggest the same event when some states have persistently high unemployment rates and others have high unemployment rates that are more transitory in nature.

We included the probability of arrest in our crime rate equations based on the hypothesis that higher values of this variable lead to lower crime rates as expected punishment from committing crimes is perceived to be higher by potential criminals. For each state, Crime in the United States: Uniform Crime Reports provides number of crimes and the crime rate per 100000 inhabitants and from these numbers we constructed the probability of arrest. Estimations found that this variable was never statistically significant and therefore we do not show these runs here as its inclusion into our model never changed the significance or sign of the other independent variables. Perhaps lack of significance is a result of having already captured this variable in our lagged crime rate variable.

\section{ESTIMATION OF CRIME AND EDUCATION SPENDING EQUATIONS}

The two stage least squares (TSLS) technique is used to estimate the model because the education and crime-related

\footnotetext{
${ }^{12}$ These numbers correspond to percentages of population, while those used in the regressions are shares of the population; i.e., percentages were derived by multiplying the shares by 100 .
} 
spending equations each contain dependent variables as right-hand-side variables. Estimation using ordinary least squares (OLS) is inappropriate for a system of equations that contain interrelationships between sets of variables.

We estimate equations for 1992 and 1985, using $i=1$, $2, \ldots 50$ states. Significance of estimated coefficients is based on two-tailed tests at the $0.01,0.05$, and 0.10 levels. Data for $E D E X P_{i}, S T U D E N T_{i}, S T A T E_{i}, F E D_{i}, S C H O O L S_{i}$ are obtained from the Digest of Education Statistics $(1992,1993)$. Data for $Y_{i}, E D U C_{i}, D E N S I T Y_{i}, C R_{i}, C C R_{i}, U E_{i}$, and $C U E_{i}$ are obtained from the Statistical Abstract of the United States (various years). Data for $C R I M E_{i}$ and $D O M_{i}$ are obtained from Table 9 of Justice Expenditure and Employment in the US, 1988 and 1992. Data on MEDAGE, $M I D 1_{i}, M I D 2_{i}$, and DIVERSIT $Y_{i}$ are obtained from US Census, Population Estimates.

Table 3 displays TSLS estimates of our three equation model using 1992 and 1985 data. Let us discuss the first three columns which display the estimates of education spending, crime spending, and the crime rate in 1992. In both cases of public spending equations, spending on one programme exerts a significant positive influence on spending on the other programme. That is, spending on crime is found to positively influence education spending, and spending on education is found to positively influence spending on crime. Contrary to claims of those who believe that spending on crime-related programmes crowds-out education spending, the influences are positive, not negative. In the education spending equation, significant influences are crime-related spending (positive), income (positive, as hypothesized), education (negative, contrary to expectations), federal share of spending (negative), and numbers of schools (positive). In the case of the crime spending equation, significant influences are education spending (positive), the contemporaneous crime rate (positive, as hypothesized), and employee dominance (positive, as hypothesized). Estimation of the crime rate equation indicates the following significant influences: previous year's crime rates (positive, as hypothesized) and the percentage of the population aged 18-24 (negative, contrary to expectations).

We now discuss the last three columns of Table 3 which display equation estimates for 1985. As in 1992, spending on one programme exerts a significant positive influence on spending on the other programme. In the education spending equation, significant influences are crime-related spending (positive), education (negative, contrary to expectations), and student share of the population (negative). The negative sign on student share of the population might arise when states that experience relatively high student-population growth find it more difficult to maintain, or increase, funding per student. For example, if it takes several years for spending to 'catch-up' with student-population increase, the short-term relationship between student-population and education spending per pupil might be negative. ${ }^{13}$ In the case of crime spending, significant influences are education spending (positive) and employee dominance (positive, as hypothesized). Estimation of the crime rate equation indicates the following significant influences: crime spending (negative), the previous year's crime rate (positive), the contemporaneous unemployment rate (negative), and the change in the unemployment rate (positive). The negative sign on the contemporaneous unemployment rate may simply indicate that, after controlling for other factors which influence crime rates, states with higher unemployment rates had lower crime rates. The same is true for the unexpected inverse relationship between the crime rate in 1992 and the percentage of the population aged 18-24. After controlling for other factors, we find that states with larger percentages of their population composed of individuals aged 18-24 had lower crime rates in 1992. Perhaps this indicates that there was an effective nationwide effort to reduce crimes committed by youth, as when police departments across the country might have instituted programmes directed toward reducing crimes in this age group. Or, it could be that individuals in the 18-24 age group have a low propensity to report crimes, so not as many crimes become know to the authorities.

\section{ESTIMATION OF CORRECTIONS AND EDUCATION SPENDING EQUATIONS}

Because the argument that crime-related spending crowdsout education spending often appears to be based on the recent growth in prisons and inmates, we now estimate our model with spending on corrections as a replacement for total crime-related spending. Measured on a per capita basis, correctional spending allows us to consider whether this particular area of crime spending crowds-out school spending, an argument often made in California.

Spending on corrections is a considerable and growing portion of total spending on crime-related programmes, and one whose magnitude varies widely across the states. While mean levels of total crime-related spending per capita are US\$273.63 (1992) and US\$155.41 (1985), mean levels of correctional spending per capita are US\$96.52 (1992) and US\$47.86 (1985). Therefore, mean percentages of total crime-related spending allocated to corrections are $35 \%$ (1992) and 31\% (1985). The range of correctional spending in 1992 is US\$224.83 (Alaska) - US\$32.28 (West Virginia); and for 1985 the range is US\$234.11 (Alaska) - \$17.38 (West Virginia).

\footnotetext{
${ }^{13}$ This has been suggested to be a major reason for why per pupil increases in education funding in California have often lagged those of other states. That is, with relatively high gains in student population, it has taken California longer to catch-up with those states that experienced relatively low gains in student populations.
} 
Table 3. T SLS estimations of public primary and secondary education spending, total crime spending, and crime rate equations, 1992 and 1985

\begin{tabular}{|c|c|c|c|c|c|c|}
\hline \multirow[b]{2}{*}{ Variable } & \multicolumn{3}{|c|}{1992} & \multicolumn{3}{|c|}{1985} \\
\hline & $\begin{array}{l}\text { Education } \\
\text { spending } \\
\text { (US\$ per } \\
\text { pupil) }\end{array}$ & $\begin{array}{l}\text { Crime } \\
\text { spending } \\
\text { (US\$ per } \\
\text { capita) }\end{array}$ & $\begin{array}{l}\text { Crime } \\
\text { rate }\end{array}$ & $\begin{array}{l}\text { Education } \\
\text { spending } \\
\text { (US\$ per } \\
\text { pupil) }\end{array}$ & $\begin{array}{l}\text { Crime } \\
\text { spending } \\
\text { (US\$ per } \\
\text { capita) }\end{array}$ & $\begin{array}{l}\text { Crime } \\
\text { rate }\end{array}$ \\
\hline Constant & $10121.6^{\mathrm{a}}$ & $\begin{array}{r}-0.23^{\mathrm{a}} \\
(4.90)\end{array}$ & $\begin{array}{r}5139.2^{\mathrm{c}} \\
(1.80)\end{array}$ & $\begin{array}{r}4973.5^{\mathrm{b}} \\
(2.58)\end{array}$ & $\begin{array}{r}-16.1^{\mathrm{a}} \\
(6.4)\end{array}$ & $\begin{array}{r}2149.4 \\
(1.37)\end{array}$ \\
\hline Crime spending & $\begin{array}{l}10.4^{\mathrm{a}} \\
(4.01)\end{array}$ & & $\begin{aligned}-211.9 \\
(0.17)\end{aligned}$ & $\begin{array}{l}10.9^{\mathrm{a}} \\
(6.31)\end{array}$ & & $\begin{array}{r}-1.68^{\mathrm{b}} \\
(2.13)\end{array}$ \\
\hline Education spending & & $\begin{array}{l}0.03^{\mathrm{a}} \\
(4.56)\end{array}$ & & & $\begin{array}{r}0.05^{\mathrm{a}} \\
(6.09)\end{array}$ & \\
\hline Income & $\begin{array}{r}0.11^{\mathrm{a}} \\
(2.74)\end{array}$ & & $\begin{array}{r}-0.01 \\
(0.71)\end{array}$ & $\begin{array}{c}0.03 \\
(1.41)\end{array}$ & & $\begin{array}{r}-0.007 \\
(0.77)\end{array}$ \\
\hline Education & $\begin{array}{r}-121.79^{b} \\
(2.59)\end{array}$ & & & $\begin{array}{r}-28.3^{\mathrm{b}} \\
(2.09)\end{array}$ & & \\
\hline Metro & $\begin{array}{r}-5.21 \\
(0.45)\end{array}$ & & & $\begin{array}{r}-3.85 \\
(0.59)\end{array}$ & & \\
\hline Student & $\begin{array}{r}-116.78 \\
(1.26)\end{array}$ & & & $\begin{array}{r}-117.5^{\mathrm{b}} \\
(2.22)\end{array}$ & & \\
\hline State & $\begin{array}{r}-12.96 \\
(1.40)\end{array}$ & & & $\begin{array}{r}-2.44 \\
(0.45)\end{array}$ & & \\
\hline Federal & $\begin{array}{r}-143.62^{\mathrm{c}} \\
(1.69)\end{array}$ & & & $\begin{array}{r}-70.3 \\
(1.50)\end{array}$ & & \\
\hline Schools & $\begin{array}{r}46296.2^{\mathrm{b}} \\
(2.31)\end{array}$ & & & $\begin{aligned} 88081.9 \\
(0.82)\end{aligned}$ & & \\
\hline Diversity & $\begin{array}{c}0.20 \\
(1.33)\end{array}$ & & $\begin{array}{r}-0.04 \\
(1.03)\end{array}$ & $\begin{array}{c}0.12 \\
(1.38)\end{array}$ & & $\begin{array}{r}-0.02 \\
(0.80)\end{array}$ \\
\hline $\begin{array}{l}\text { Crime rate } \\
\text { (contemporaneous) }\end{array}$ & & $\begin{array}{l}3.13 \mathrm{E}-0 \\
(3.10)\end{array}$ & & & $\begin{array}{c}0.007 \\
(1.22)\end{array}$ & \\
\hline Crime rate (1 year lag) & & & $\begin{array}{l}0.90^{\mathrm{a}} \\
(17.7)\end{array}$ & & & $\begin{array}{l}1.11^{\mathrm{a}} \\
(28.3)^{-}\end{array}$ \\
\hline $\begin{array}{l}\text { Crime rate change } \\
\text { (three-year) }\end{array}$ & & $\begin{array}{l}1.03 \mathrm{E}-0 \\
(0.52)\end{array}$ & & & $\begin{array}{l}0.008 \\
(0.55)\end{array}$ & \\
\hline Median age & & & $\begin{aligned}-61.5 \\
(1.41)\end{aligned}$ & & & $\begin{aligned} &- 18.9 \\
&(0.86)\end{aligned}$ \\
\hline Pop 18-24 & & & $\begin{array}{r}-200.0^{\mathrm{c}} \\
(1.85)\end{array}$ & & & $\begin{array}{r}-86.5 \\
(1.43)\end{array}$ \\
\hline Pop 25-44 & & & $\begin{array}{l}1.51 \\
(0.04)\end{array}$ & & & $\begin{array}{l}4.06 \\
(0.17)\end{array}$ \\
\hline Employee dominance & & $\begin{array}{c}26778.0^{\mathrm{b}} \\
(2.30)\end{array}$ & & & $\begin{array}{r}24673.7^{\mathrm{a}} \\
(2.90)\end{array}$ & \\
\hline Unemployment rate & & & $\begin{array}{c}3.26 \\
(0.08)\end{array}$ & & & $\begin{array}{r}-34.59^{\mathrm{c}} \\
(1.73)\end{array}$ \\
\hline $\begin{array}{l}\text { Change in unemployment } \\
\text { rate (three-year) }\end{array}$ & & & $\begin{array}{r}-19.93 \\
(0.32)\end{array}$ & & & $\begin{array}{r}36.96^{\mathrm{c}} \\
(1.69)\end{array}$ \\
\hline Adjusted $R^{2}$ & 0.67 & 0.73 & 0.95 & 0.79 & 0.78 & 0.96 \\
\hline SEE & 761.9 & 0.05 & 268.2 & 466.0 & 36.1 & 201.2 \\
\hline$F$ & $12.0^{\mathrm{a}}$ & $33.8^{\mathrm{a}}$ & $108.1^{\mathrm{a}}$ & $20.7^{\mathrm{a}}$ & $42.8^{\mathrm{a}}$ & $220.5^{\mathrm{a}}$ \\
\hline
\end{tabular}

$t$-statistics below estimated coefficients.

a, b, csignificance at $1,5,10 \%$ levels (2-tailed tests) or greater. 
Table 4 displays the TSLS estimates of spending on state and local education and correctional programmes, and the crime rate. The first three columns show the estimates for 1992. In both cases of public spending equations, spending on one programme exerts a significant positive influence on spending on the other programme. That is, spending on corrections is found to positively influence education spending, and spending on education is found to positively influence spending on corrections. In the education spending equation, significant influences are crime-related spending (positive), income (positive, as hypothesized), education (negative, contrary to expectations), and numbers of schools (positive). The results indicate an inverse relationship between education spending per pupil and the percentage of the population with at least a high school degree. A possible explanation for this is that parents without a high school degree realize how important a degree is, and are willing to support increased levels of spending to improve the educational success of their offspring.

In the case of the corrections spending equation, significant influences are education spending (positive), the contemporaneous crime rate (positive, as hypothesized), and employee dominance (positive, as hypothesized). Estimation of the crime rate equation indicates the following significant influences: previous year's crime rates (positive, as hypothesized) and the percentage of the population aged 18-24 (negative, contrary to expectations).

The last three columns of Table 4 display equation estimates for 1985. As in 1992, spending on one programme exerts a significant positive influence on spending on the other programme. In the education spending equation, significant influences are crime-related spending (positive), income (positive, as hypothesized), student share of the population (negative), and the federal share of funding (negative). As previously suggested, the negative sign on student share of the population might arise when states that experience relatively high student-population growth find it more difficult to maintain, or increase, funding per student. In the corrections spending equation, significant influences are education spending (positive) and employee dominance (positive, as hypothesized). Estimation of the crime rate equation indicates the following significant influences: corrections spending (negative, as hypothesized), the previous year's crime rate (positive), and the change in the unemployment rate (positive).

\section{ESTIMATIONS USING PERCENTAGE CHANGES OVER 1995-1988}

Table 5 displays estimates of spending and crime rate equations where these variables are measured as percentage changes over 1992-1985. These equations were estimated in order to determine how changes in these variables over this time period influenced one another. As with the dependent variables, we also calculated percentage changes in all explanatory variables. These models are another approach to determining whether crime-related spending crowded-out spending on education over this period.

The first three columns display estimations of percentage changes in education spending per pupil, total crimerelated spending, and the crime rate. Estimations of these relationships mirror the results from our previous estimations that focused on single-year relationships. That is, each programme exerts a positive influence on the other over this time period. Therefore, there is no evidence that either programme crowded-out the other over this time frame.

In the education spending equation, significant influences are crime-related spending (positive), student-share of the population (negative), and diversity (positive, contrary to expectations). In the equations for the percentage change in education spending per pupil between 1992 and 1985, the diversity variable is positive and we hypothesized a negative sign. The positive relationship between the diversity variable and expenditure per pupil means that those states whose populations became more racial/ethnically homogeneous had the greatest percentage increases in expenditure per pupil. This may suggest that individuals prefer to locate in homogeneous communities, and when the community makeup changes towards the preferred homogeneous one, they are willing to increase spending on their children's education. Also, it could be that greater racial/ethnic diversity among the population gives rise to demands for a greater variety of public expenditure programmes, and with a greater variety of public expenditure programmes there is less expenditure per programme, including education.

In the crime spending equation, significant influences are education spending (positive) and crime-related employees as a share of the population (positive, as hypothesized). In the crime rate equation, significant influences are the lagged crime rate (positive) and median age of the population (positive). Interestingly, the percentage change in total crime-related spending does not exert a statistically significant influence on the percentage change in the crime rate over this period.

The last three columns display estimations of percentage changes in education spending per pupil, correctional spending per capita, and the crime rate. While both spending programmes are found to exert positive influences on each other, only one programme (corrections) is estimated to exert a statistically significant influence on the other programme (education). In the education spending equation, significant influences are corrections (positive), student share of the population (negative), federal share of funding (negative), and diversity (positive, contrary to expectations). In the correctional spending equation, the only significant influence is employee dominance (positive, as hypothesized). Estimation of the crime rate equation reveals the lagged 
Table 4. TSLS estimation of public primary and secondary education spending, corrections spending, and crime rate equations, 1992 and 1985

\begin{tabular}{|c|c|c|c|c|c|c|}
\hline \multirow[b]{2}{*}{ Variable } & \multicolumn{3}{|c|}{1992} & \multicolumn{3}{|c|}{1985} \\
\hline & $\begin{array}{l}\text { Education } \\
\text { spending } \\
\text { (US\$ per } \\
\text { pupil) }\end{array}$ & $\begin{array}{l}\text { Crime } \\
\text { spending } \\
\text { (US\$ per } \\
\text { capita) }\end{array}$ & $\begin{array}{l}\text { Crime } \\
\text { rate }\end{array}$ & $\begin{array}{l}\text { Education } \\
\text { spending } \\
\text { (US\$ per } \\
\text { pupil) }\end{array}$ & $\begin{array}{l}\text { Corrections } \\
\text { spending } \\
\text { (US\$ per } \\
\text { capita) }\end{array}$ & $\begin{array}{l}\text { Crime } \\
\text { rate }\end{array}$ \\
\hline Constant & $\begin{array}{r}49469.6^{\mathrm{a}} \\
(2.96)\end{array}$ & $\begin{array}{r}-0.11^{\mathrm{a}} \\
(4.97)\end{array}$ & $\begin{array}{l}5223.7^{\mathrm{c}} \\
(1.97)\end{array}$ & $\begin{array}{r}5696.4^{\mathrm{b}} \\
(2.62)\end{array}$ & $\begin{array}{r}-68.97^{\mathrm{a}} \\
(5.58)\end{array}$ & $\begin{array}{l}2072.1 \\
\quad(1.28)\end{array}$ \\
\hline Corrections spending & $\begin{array}{l}14.09^{\mathrm{b}} \\
(2.70)\end{array}$ & & $\begin{array}{r}-1259.4 \\
(0.56)\end{array}$ & $\begin{array}{r}18.54^{\mathrm{a}} \\
(4.02)\end{array}$ & & $\begin{array}{r}-3.39^{\mathrm{c}} \\
(1.75)\end{array}$ \\
\hline Education spending & & $\begin{array}{r}0.02^{\mathrm{a}} \\
(5.46)\end{array}$ & & & $\begin{array}{r}0.02^{\mathrm{a}} \\
(6.69)\end{array}$ & \\
\hline Income & $\begin{array}{r}0.13^{\mathrm{a}} \\
(3.03)\end{array}$ & & $\begin{array}{r}-0.01 \\
(0.82)\end{array}$ & $\begin{array}{r}0.05^{\mathrm{c}} \\
(1.96)\end{array}$ & & $\begin{array}{r}-0.012 \\
(1.29)\end{array}$ \\
\hline Education & $\begin{array}{r}-81.27^{\mathrm{c}} \\
(1.69)\end{array}$ & & & $\begin{array}{r}-17.22 \\
(1.14)\end{array}$ & & \\
\hline Metro & $\begin{array}{r}-3.91 \\
(0.31)\end{array}$ & & & $\begin{array}{r}-5.70 \\
(0.76)\end{array}$ & & \\
\hline Student & $\begin{array}{r}-154.23 \\
(1.56)\end{array}$ & & & $\begin{array}{r}-133.97^{\mathrm{b}} \\
(2.23)\end{array}$ & & \\
\hline State & $\begin{array}{r}-10.23 \\
(1.03)\end{array}$ & & & $\begin{array}{r}-0.46 \\
(0.07)\end{array}$ & & \\
\hline Federal & $\begin{array}{r}-147.41 \\
(1.61)\end{array}$ & & & $\begin{array}{r}-107.19^{\mathrm{c}} \\
(2.02)\end{array}$ & & \\
\hline Schools & $\begin{array}{r}494745.1^{\mathrm{b}} \\
(2.29)\end{array}$ & & & $\begin{array}{r}110590.2 \\
(0.91)\end{array}$ & & \\
\hline Diversity & $\begin{array}{c}0.04 \\
(0.29)\end{array}$ & & $\begin{array}{r}-0.05 \\
(1.19)\end{array}$ & $\begin{array}{c}0.03 \\
(0.28)\end{array}$ & & $\begin{array}{r}-0.02 \\
(0.72)\end{array}$ \\
\hline $\begin{array}{l}\text { Crime rate } \\
\text { (contemporaneous) }\end{array}$ & & $\begin{array}{l}1.19 \mathrm{E}-0 \\
(2.63)\end{array}$ & & & $\begin{array}{l}0.0008 \\
(0.33)\end{array}$ & \\
\hline Crime rate (1 year lag) & & & $\begin{array}{l}0.90^{\mathrm{a}} \\
(17.6)\end{array}$ & & & $\begin{array}{l}1.11^{\mathrm{a}} \\
(27.8)\end{array}$ \\
\hline $\begin{array}{l}\text { Crime rate change } \\
\text { (three-year) }\end{array}$ & & $\begin{array}{l}1.40 \mathrm{E}-0 \\
(1.56)\end{array}$ & & & $\begin{array}{c}0.009 \\
(1.38)\end{array}$ & \\
\hline Median age & & & $\begin{array}{r}-66.13 \\
(1.59)\end{array}$ & & & $\begin{array}{r}-20.34 \\
(0.91)\end{array}$ \\
\hline Pop 18-24 & & & $\begin{array}{r}-211.14^{\mathrm{b}} \\
(2.25)\end{array}$ & & & $\begin{array}{r}-73.69 \\
(1.19)\end{array}$ \\
\hline Pop 25-44 & & & $\begin{array}{l}9.78 \\
(0.80)\end{array}$ & & & $\begin{array}{l}4.39 \\
(0.17)\end{array}$ \\
\hline Employee dominance & & $\begin{array}{c}31339.0^{\mathrm{a}} \\
(3.08)\end{array}$ & & & $\begin{array}{r}28543.2^{\mathrm{a}} \\
(4.09)\end{array}$ & \\
\hline Unemployment rate & & & $\begin{array}{c}2.14 \\
(0.05)\end{array}$ & & & $\begin{array}{r}-35.4^{\mathrm{c}} \\
(1.71)\end{array}$ \\
\hline $\begin{array}{l}\text { Change in unemployment } \\
\text { rate (three-year) }\end{array}$ & & & $\begin{aligned}- & 12.9 \\
& (0.21)\end{aligned}$ & & & $\begin{array}{c}34.47^{c} \\
(1.55)\end{array}$ \\
\hline Adjusted $R^{2}$ & 0.62 & 0.70 & 0.95 & 0.73 & 0.70 & 0.97 \\
\hline SEE & 822.9 & 0.22 & 265.4 & 527.2 & 16.9 & 205.0 \\
\hline$F$ & $9.60^{\mathrm{a}}$ & $31.1^{\mathrm{a}}$ & $110.4^{\mathrm{a}}$ & $14.52^{\mathrm{a}}$ & $28.8^{\mathrm{a}}$ & $212.3^{\mathrm{a}}$ \\
\hline
\end{tabular}

$t$-statistics below estimated coefficients.

a, b, c significance at $1,5,10 \%$ levels (2-tailed tests) or greater. 
Table 5. T SLS estimations of public primary and secondary education spending, total crime spending, and crime rate equations, percentage change between 1992 and 1985

\begin{tabular}{|c|c|c|c|c|c|c|}
\hline \multirow[b]{2}{*}{ Variable } & \multicolumn{3}{|c|}{ Total } & \multicolumn{3}{|c|}{ Corrections } \\
\hline & $\begin{array}{l}\text { Education } \\
\text { spending } \\
\text { (US\$ per } \\
\text { pupil) }\end{array}$ & $\begin{array}{l}\text { Crime } \\
\text { spending } \\
\text { (US\$ per } \\
\text { capita) }\end{array}$ & $\begin{array}{l}\text { Crime } \\
\text { rate }\end{array}$ & $\begin{array}{l}\text { Education } \\
\text { spending } \\
\text { (US\$ per } \\
\text { pupil) }\end{array}$ & $\begin{array}{l}\text { Corrections } \\
\text { spending } \\
\text { (US\$ per } \\
\text { capita) }\end{array}$ & $\begin{array}{l}\text { Crime } \\
\text { rate }\end{array}$ \\
\hline Constant & $\begin{array}{r}-1.95 \\
(0.14)\end{array}$ & $\begin{array}{l}52.18 \\
(8.85)\end{array}$ & $\begin{array}{r}-11.89 \\
(0.95)\end{array}$ & $\begin{array}{r}-16.59^{b} \\
(2.08)\end{array}$ & $\begin{array}{r}52.81^{\mathrm{a}} \\
(3.82)\end{array}$ & $\begin{array}{r}-17.15^{\mathrm{c}} \\
(1.82)\end{array}$ \\
\hline $\begin{array}{l}\text { Crime/correction } \\
\text { spending }\end{array}$ & $\begin{array}{r}-0.31^{\mathrm{b}} \\
(2.42)\end{array}$ & & $\begin{array}{r}-0.04 \\
(0.49)\end{array}$ & $\begin{array}{r}0.08^{\mathrm{c}} \\
(1.83)\end{array}$ & & $\begin{array}{r}0.002 \\
(0.405)\end{array}$ \\
\hline Education spending & & $\begin{array}{r}0.53^{\mathrm{c}} \\
(1.98)\end{array}$ & & & $\begin{array}{c}0.92 \\
(1.67)\end{array}$ & \\
\hline Income & $\begin{array}{c}0.03 \\
(0.11)\end{array}$ & & $\begin{array}{r}-0.05 \\
(0.30)\end{array}$ & $\begin{array}{c}0.14 \\
(0.55)\end{array}$ & & $\begin{array}{r}-0.09 \\
(0.58)\end{array}$ \\
\hline Education & $\begin{array}{c}0.14 \\
(0.36)\end{array}$ & & & $\begin{array}{c}0.08 \\
(0.20)\end{array}$ & & \\
\hline Metro & $\begin{array}{r}-0.10 \\
(0.65)\end{array}$ & & & $\begin{array}{r}-0.13 \\
(0.82)\end{array}$ & & \\
\hline Student & $\begin{array}{r}-0.90^{c} \\
(1.85)\end{array}$ & & & $\begin{array}{r}-0.95^{\mathrm{c}} \\
(2.00)\end{array}$ & & \\
\hline State & $\begin{array}{c}0.04 \\
(0.43)\end{array}$ & & & $\begin{array}{c}0.01 \\
(0.12)\end{array}$ & & \\
\hline Federal & $\begin{array}{r}-0.016 \\
(0.30)\end{array}$ & & & $\begin{array}{r}-0.07^{\mathrm{c}} \\
(1.86)\end{array}$ & & \\
\hline Schools & $\begin{array}{c}0.21 \\
(0.82)\end{array}$ & & & $\begin{array}{l}0.17 \\
(0.68)\end{array}$ & & \\
\hline Diversity & $\begin{array}{r}0.67^{\mathrm{c}} \\
(1.89)\end{array}$ & & $\begin{array}{c}0.02 \\
(0.09)\end{array}$ & $\begin{array}{r}0.76^{\mathrm{b}} \\
(2.20)\end{array}$ & & $\begin{array}{c}0.02 \\
(0.08)\end{array}$ \\
\hline Crime rate & & $\begin{array}{r}-0.26 \\
(1.20)\end{array}$ & & & $\begin{array}{r}-0.38 \\
(0.79)\end{array}$ & \\
\hline Crime rate (1 year lag) & & & $\begin{array}{r}0.75^{\mathrm{a}} \\
(9.78)\end{array}$ & & & $\begin{array}{r}0.75^{\mathrm{a}} \\
(9.74)\end{array}$ \\
\hline $\begin{array}{l}\text { Crime rate change } \\
\text { (three-year) }\end{array}$ & & $\begin{array}{c}-0.0002 \\
(0.15)\end{array}$ & & & $\begin{array}{r}-0.002 \\
(0.53)\end{array}$ & \\
\hline Median age & & & $\begin{array}{r}1.08^{\mathrm{c}} \\
(1.83)\end{array}$ & & & $\begin{array}{r}1.22^{\mathrm{b}} \\
(2.23)\end{array}$ \\
\hline Pop 18-24 & & & $\begin{array}{r}-0.05 \\
(0.19)\end{array}$ & & & $\begin{array}{r}-0.06 \\
(0.21)\end{array}$ \\
\hline Pop 25-44 & & & $\begin{array}{r}0.40 \\
(0.89)\end{array}$ & & & $\begin{array}{c}0.38 \\
(0.84)\end{array}$ \\
\hline Employee dominance & & $\begin{array}{r}1.26^{\mathrm{a}} \\
(3.62)\end{array}$ & & & $\begin{array}{r}1.27^{\mathrm{a}} \\
(4.63)\end{array}$ & \\
\hline Unemployment rate & & & $\begin{array}{r}-0.05 \\
(1.42)\end{array}$ & & & $\begin{array}{r}-0.05 \\
(1.44)\end{array}$ \\
\hline $\begin{array}{l}\text { Change in unemployment } \\
\text { rate (three-year) }\end{array}$ & & & $\begin{array}{c}-0.005 \\
(0.95)\end{array}$ & & & $\begin{array}{r}-0.007 \\
(1.59)\end{array}$ \\
\hline Adjusted $R^{2}$ & 0.34 & 0.36 & 0.76 & 0.38 & 0.37 & 0.76 \\
\hline SEE & 10.37 & 17.05 & 6.16 & 9.98 & 38.53 & 6.18 \\
\hline$F$ & $4.67^{\mathrm{a}}$ & $8.89^{\mathrm{a}}$ & $18.6^{\mathrm{a}}$ & $4.70^{\mathrm{a}}$ & $8.46^{\mathrm{a}}$ & $18.4^{\mathrm{a}}$ \\
\hline
\end{tabular}

$t$-statistics below estimated coefficients.

a, b,c significance at 1, 5, 10\% levels (2-tailed tests) or greater. 
crime rate (positive) and median age (positive) as significant influences.

\section{CONCLUSIONS}

Estimation of our models suggests no evidence that crimerelated programmes have crowded-out spending on education in 1992, 1985, or between the period 1985-92 at the level of state and local governments. However, our empirical analysis provides strong support for a positive relationship between these areas of public spending. In other words, 'big' spenders on education tended to be 'big' spenders on crime as well because those states that allocated relatively large levels of resources to one programme also allocated a relatively large level of resources to the other programme. Moreover, when spending on correctional programmes is substituted for total spending on crime, this same result appears in most cases as well: those states with relatively high resource commitments to education programmes also provide relatively high resource commitments to correctional programmes. These results indicate that spending decisions on these programmes do not arise within an environment of a zero-sum game; i.e., a spending increase in one programme is not funded by decreasing funding commitment to the other programme. Rather, increases in either of these programmes are funded through either reductions in other programmes, general tax increases, or issuance of additional public debt. Which of these options appears most likely cannot be answered within our paper's framework and therefore remains an interesting and open research issue.

Another area for future research would be to examine what influence, if any, 'three strikes' laws may exert on education programmes. Because 'three strikes' laws are relatively new, and have not been passed by all states, data are not readily available with which to examine the effects of such laws on education programmes. However, while it may be true that future relationships between spending on education and crime-related programmes may change into ones that are consistent with the crowding-out hypothesis, it should be noted that the empirical evidence presented here is consistent with the previous literature and offers no support for the hypothesis that any particular spending programme crowds-out any other spending programme of state or local governments.

\section{REFERENCES}

Brazer, H. and McCarty, T. (1987) Interaction between demand for education and for municipal services, National Tax Journal, 40, 555-66.

Brennan, G. and Buchanan, J. M. (1980) The Power to Tax: Analytical Foundations of a Fiscal Constitution, Cambridge University Press, Cambridge.

Buck, A. J. (1996) A transitional gains trap: prison sentences and prison capacity, Social Science Quarterly, 77, 260-64.

Brumm, H. J. and Cloninger, D. O. (1995) The drug war and the homicide rate: a direct correlation, Cato Journal, 14, 509-17

Clark, J. R. and Lee, D. R. (1996) Sentencing Laffer curves, political myopia, and prison space, Social Science Quarterly, 77, 245-55.

Cloninger, D. O. (1996) Sentence length, severity, and the demand for prison space, Social Science Quarterly, 77, 265-68.

Federal Bureau of Investigation (1992) Crime in the United States: Uniform Crime Reports for the United States, 1992, US Department of Justice, US Government Printing Office, Washington, DC.

Fossett, J. W. and Wykoff, J. H. (1996) Has Medicaid growth crowded our state educational spending?, Journal of Health Politics, Policy and Law, 21, 409-32.

Greenwood P., Rydell, C., Abrahamse, A., Caulkins, J., Chiesa, J., Model, K. and Klein, S. (1994) Three Strikes and You're Out, Rand Corporation, Santa Monica, CA.

Kenny, L. W. and Schmidt, A. B. (1994) The decline in the number of school districts in the US: 1950-1980, Public Choice 79, $1-18$.

Logan, R. .R (1986) Fiscal illusion and the grantor government, Journal of Political Economy, 96, 1304-18.

Marlow, M. L. (1997) Public education supply and student performance, Applied Economics, 29, 617-26.

McCarty, T. A. and Schmidt, S. J. (1997) A vector autoregression analysis of state government expenditure, American Economic Review (papers and proceedings), 87, 278-82.

Peltzman, S. (1993) The political economy of the decline of American public education, Journal of Law and Economics, XXXVI, 331-70.

Smith, M. D. (1996) Commentary: The folly of a 'Lock 'Em Up' Laffer curve, Social Science Quarterly, 77, 260-64.

US Department of Commerce (various) Statistical Abstract of the United States, Washington, DC.

US Department of Education (1992-3) Digest of Education Statistics, National Center for Education Statistics, Washington, DC.

Winer, S. L. (1983) Some evidence on the effect of the separation of spending and taxing decisions, Journal of Political Economy, 91(X), 126-40. 